\author{
MONIKA PAKURA \\ (D) https://orcid.org/0000-0002-8016-8158 \\ Uniwersytet Śląski \\ Katowice
}

\title{
Edukacja dzieci romskich oczami nauczyciela. Przestrzenie nieodkryte
}

\author{
Education of Romani children. \\ Undiscovered spaces
}

\begin{abstract}
The paper presents the educational situation of Romani children in Poland. It reflects on the actions of the Polish state contributing to the improvement of the process of educating Romani people. Referring to the subject literature and to experience in work with Romani children, the paper also indicates areas that require constant support and actions aimed at improving the quality of Romani education. Consequently, these considerations represent an analysis and an attempt to verify the practical manifestation of the Romani people's attitude towards school and its actions in favour of children from the Romani ethnic minority.
\end{abstract}

Key words: Romani children, education, intercultural education

\section{Edukacja Romów na ziemiach polskich - początki}

Romowie to grupa etniczna wywodząca się z Indii, która do Polski przybyła bezpośrednio z terenów Węgier. Dowodzą tego akta parafialne i umieszczone w nich wzmianki na temat Cyganów (Kunikowski 2010, 179).

\footnotetext{
1 Artykuł opiera się na moim ośmioletnim doświadczeniu w pracy z uczniami romskimi $\mathrm{i}$ ich rodzinami. W związku $\mathrm{z}$ tym jest nie tylko zbiorem tez pochodzacych $\mathrm{z}$ literatury przedmiotu, ale także tych wynikających z codziennej pracy w szkole. Część wniosków powstała na podstawie badań sprawności językowej i komunikacyjnej dzieci romskiej mniejszości etnicznej, jakie prowadziłam w trakcie trwania studiów doktoranckich. Ich wyniki opisuję w przygotowywanej rozprawie - M.P.
} 
Koczowniczy tryb życia, jaki Romowie prowadzili, spowodował, że do dziś żyja rozproszeniu, przez co stanowią grupę mniejszościową uzależniająca jakość własnego funkcjonowania od populacji dominującej (Mirga, Mróz 1994, 138; za: Gerlich 2001, 21). Według danych Narodowego Spisu Powszechnego z 2011 roku w Polsce mieszka około 20-30 tysięcy Romów², wśród których wyróżnić można cztery szczepy cygańskie: Bergitka Roma, Kełderaszów, Lowarów, a także Polska Roma inaczej zwana Romami Nizinnymi (Lubecka 2005). Każda z grup zamieszkuje inny teren Polski i posiada odmienny status społeczny. Osoby należące do konkretnych grup posługują się także różnymi, często niezrozumiałymi dla siebie wzajemnie, dialektami. Istnieje jednak coś, co łączy Romów jako mniejszość etniczną, a jest to kultura oraz towarzyszący jej

prymat tradycji nad modyfikacją i innowacją, wieloaspektowy izolacjonizm, międzygeneracyjny przekaz tradycji oparty na zasadzie face to face, jedynie oralne utrwalanie historii i tradycji, wyraźna anatema wobec alternatywnych rozwiązań kulturowych i społecznych przy jednoczesnej umiejętności częściowej adaptacji - w ustalonym z punktu widzenia interesu zbiorowego - do obcego środowiska (Gerlich 2001, 18).

Odwołując się do słów Mariana Grzegorza Gerlicha, można stwierdzić, że transfer kultury, tradycji, obyczajów i języka Romów odbywa się głównie droga ustna, a styl ich życia dziedziczony jest z pokolenia na pokolenie. W związku z tym usamodzielnienie się i uniezależnienie ekonomiczne od rodziny oraz tradycyjnego stylu życia nigdy nie było dla Romów czymś pożądanym (Kwadrans 2008, 62). Romowie, czując się członkami wielopokoleniowej rodziny i pielęgnując wraz z nią romskie tradycje, a przede wszystkim przestrzegając romanipen ${ }^{3}$, przyjmowali role społeczne i światopogląd przekazywany przez najbliższe otoczenie ${ }^{4}$. Przynależność do rodziny, która obyczajowo i mentalnie stanowi część plemienia, była swoistą legitymacją potwierdzającą wierność tradycji (Jakimik, Parno-Gierliński 2009, 39). Od rodziców i dalszej rodziny młodzi Romowie nabywali więc niezbędnych

\footnotetext{
2 Dane za: Struktura narodowo-etniczna, jezykowa i wyznaniowa ludności Polski, https://stat.gov.pl /spisy-powszechne/nsp-2011/ [dostęp: 5.04.2019].

${ }^{3}$ Kodeks romski, zbiór norm i zasad.

4 Wiąże się to silnie z procesem socjalizacji pierwotnej, w której najbliższe otoczenie dziecka, rodzina będąca naturalnym i pierwotnym środowiskiem wychowania, kształtuje osobowość społeczną ludzi tworzących społeczeństwo (Warchala, Skudrzyk 2010, 22).
} 
do przeżycia umiejętności - chłopcy od najmłodszych lat przyuczani byli do charakterystycznych dla Romów zawodów m.in. kowalstwa, handlu czy gry na instrumentach, a dziewczyny dbały o gospodarstwo domowe i zajmowały się wróżbą (Kwadrans 2008). Życie w taborze wśród bliskich było zatem czymś szczególnie wartościowym, ale jednocześnie utrudniało zdobywanie wykształcenia. Ciagłe wędrówki uniemożliwiały bowiem wysyłanie dzieci do szkół i pilnowanie, by realizowały obowiązek szkolny. „Cyganie byli więc nieznani i wolni (...), a zatem łamali bezpieczne wyobrażenie o ustalonym porządku” (Różycka 2009, 15).

Tym, co mogło mieć jakikolwiek wpływ na romski tryb życia i przełamać dotychczasowe o nich wyobrażenia, było zaostrzenie polityki państwa wobec romskiej mniejszości etnicznej. W roku 1777 uchwalono reformę Ratio educationis, na mocy której wprowadzono obowiązek szkolny wobec dzieci romskich. Niestety, wspomniana reforma wniosła niewiele zmian, władze lokalne nie egzekwowały bowiem od rodzin romskich wypełniania nałożonego obowiązku (Kwadrans 2008). W związku z tym ich sytuacja wciąż pozostawała trudna, „Cyganie (...) należeli do najbardziej upośledzonych prawnie i materialnie grup ludności" (Gurbiel 2011, 24), byli niewykształceni, biedni i pozbawieni własnej ziemi. Rzadko zdarzały się więc ambiwalentne postawy wobec nich, $z$ reguły były one negatywne, a sami Romowie i jako grupa, i jako jednostki byli u dołu drabiny społecznej (Hertz 1960). Sytuacja zaczęła się zmieniać za sprawą uchwały z 24 maja 1952 roku wprowadzonej przez Prezydium Rządu i zatytułowanej O pomocy ludności cygańskiej pray przechodzeniu na osiadty tryb sycia. Celem tej ustawy było wymuszenie na Romach zaniechania prowadzenia wędrownego stylu życia, ewidencjonowanie ich, narzucenie obowiązku służby wojskowej i kierowania dzieci do polskich szkól. W roku 1964 ostatecznie zakazano Romom wędrować z taborami i nakazano się osiedlić, ponieważ „w warunkach wędrowania obowiązek szkolny nie był realizowany. Dopiero kiedy wędrowni Romowie zostali osiedleni, przymus ten egzekwowano, traktując go również jako jeden $z$ instrumentów karno-administracyjnych pomocnych w procesie osadnictwa. Wtedy to dopiero romskie dzieci w większej ilości trafiły do szkół" (Program na ržecz spoteczności romskiej, 2003b). Liczono, że Romowie skuszą się na taką formę życia, jednak przymusowa akcja osiedleńcza dla wielu z nich była nieszczęściem i karą (Bartosz 2008). Mimo to podejmowano próby wysyłania dzieci do szkół, wprowadzono nawet funkcję tzw. cygańskiego opiekuna społecznego (Kwadrans 2008), którego zadaniem było kontrolowanie rodzin romskich $\mathrm{i}$ angażowanie ich w życie 
szkoły. Również i te rozwiązania okazały się niewystarczające, by zmienić stosunek Romów do placówek oświatowych, zwłaszcza że „szkoła, a co za tym idzie, szeroko rozumiana edukacja, była odbierana (...) jako zamach na cygańszczyznę (...), stała się złem koniecznym, z definicji odbieranym jako zagrożenie dla tożsamości kulturowej" (Różycka 2009, 22). Po wprowadzeniu uchwały sytuacja edukacyjna poprawiła się, gdyż na rodziców dzieci niewypełniających obowiązku szkolnego nakładano kary finansowe. Jednak i to nie trwało długo. Również po roku 1989, gdy „upadek komunizmu zapoczątkował trudną drogę przemian w kierunku demokracji i gospodarki rynkowej (...), nowej liberalizacji i demokratyzacji towarzyszyło przyznanie mniejszościom, w tym Romom, prawa do udziału w życiu publicznym i politycznym" (Mirga, Gheorghe 1998, 24), mimo początkowej aktywizacji nie zrealizowano zamierzonych celów związanych z poprawą sytuacji edukacyjnej Romów w Polsce. Wciąż zmagano się z niskim wskaźnikiem scholaryzacji, a wysokim bezrobocia, aktami nietolerancji i agresji wobec romskiej mniejszości, a także z niechęcią Romów do jakichkolwiek prób ich asymilacji ze społeczeństwem polskim. Awersja cygańskiej starszyzny do oświaty rosła, problemy dzieci z promocją do następnych klas, trudności w nauce i komunikacji oraz różnice kulturowe powodowały, że coraz mniejsza liczba romskich uczniów uzyskiwała elementarne wykształcenie (Mróz 1966, za: Kwadrans 2008). Sytuację tymczasowo zmieniło wprowadzenie tzw. klas romskich (do których uczęszczali wyłącznie Romowie), założonych na południu kraju przez ks. Stanisława Opockiego. Rozwiązanie to miało na celu przede wszystkim naukę pisania i czytania, a także umożliwienie najmłodszym dzieciom romskim pokonywania barier edukacyjno-adaptacyjnych i przygotowanie do nauki w klasach wyższych (Kwadrans 2008). Niestety projekt ten, mimo iż został przez większość Romów zaakceptowany i cieszył się wśród nich popularnością przez cygańskich działaczy traktowany był jako próba gettoizacji i działanie utrwalające podziały rasowe (Kwadrans 2008). W związku z tym od roku 2003 klasy romskie zaczęto wygaszać, chociaż przyczyniły się one do poprawy sytuacji edukacyjnej Romów i były jednym z niewielu działań stanowiących szansę dla opóźnionych edukacyjnie dzieci romskich.

Obecnie - decyzją Ministerstwa Edukacji Narodowej - wszystkie dzieci uczą się w polsko-romskich klasach integracyjnych ${ }^{5}$, a wśród Romów - jak podaje Ministerstwo Spraw Wewnętrznych i Administracji - panuje przeko-

\footnotetext{
5 Pisząc o klasach integracyjnych, mam na myśli takie, w których uczą się Romowie i Polacy.
} 
nanie, że „edukacja jest warunkiem koniecznym pełnoprawnego uczestnictwa (...) w nowoczesnym świecie. Liderzy romscy zdali sobie sprawę, że brak wykształcenia, czy wręcz analfabetyzm, są jednym z najważniejszych powodów niskiego statusu społecznego i upośledzenia ekonomicznego dużej części Romów” (Program na rzecz. spoleczności romskiej, 2003a).

\section{Edukacja Romów dziś, czyli z czym mierzą się dzieci romskiej mniejszości etnicznej}

Szkoła to miejsce neutralne, które daje uczniom podwaliny do wykształcenia nowej tożsamości zbiorowej - wspólnoty szkolnej (Bernacka-Langier $i$ in. 2010). Ponadto ma za zadanie wspierać uczniów w zachowywaniu ich tożsamości narodowej, etnicznej, religijnej, a także w zachowaniu języka (Ustawa o systemie oświaty..., art. 13). Tym samym powinna promować postawy wolne od uprzedzeń, pełne szacunku i akceptacji, a także uwzględniać indywidualne potrzeby uczniów. Taki obraz szkoły zdecydowanie ma zachęcać mniejszości różnych narodowości do nauki i zdobywania wykształcenia, tym bardziej że na każdym etapie kształcenia podstawa programowa realizuje zakres tematyczny związany z tożsamością narodowa, co ma wpływ na promowanie w szkole i klasie postaw akceptacji dla inności (Przybyszewska 2014). Mimo to - jak wynika z moich obserwacji ${ }^{1}$ i doświadczenia nauczyciela wychowawcy - nie wszyscy Romowie regularnie realizują obowiązek szkolny ${ }^{7}$, co spowodowane jest faktem, że część z nich opuszcza kraj w celach zarobkowych (większość po kilku miesiącach wraca na stałe do Polski), część opiekuje się młodszym rodzeństwem i pomaga w pracach domowych, a w przypadku młodych dziewczyn, rzadziej chłopców - zakłada własną rodzinę. Opisane sytuacje nie są spotykane w środowisku romskim nagminnie, jednak wciąż się zdarzają i mają negatywny wpływ na realizację przez uczniów pochodzenia romskiego obowiązku szkolnego.

${ }^{6} \mathrm{~W}$ swojej ośmioletniej pracy prowadziłam zajęcia wspomagające rozwój języka u dzieci romskich, zajęcia wyrównawcze z języka polskiego, a także zajęcia dla dzieci z trudnościami w czytaniu i pisaniu. Na każde z tych lekcji uczęszczały dzieci romskie, co nie tylko pozwoliło mi szukać nowych rozwiązań i form pracy z nimi, ale również umożliwiło nawiązanie kontaktu $\mathrm{z}$ ich rodzinami.

7 Lukasz Kwadrans w swoim studium porównawczym, dotyczącym sytuacji edukacyjnej Romów w Polsce, Czechach i na Słowacji, podaje, że około 30\% dzieci romskich nie realizuje obowiązku szkolnego. 
Postrzeganie szkoły przez społeczność romską determinuje także ustanawiająca wzór romskiej kultury starszyzna, która „w przeważającej większości wypadków pozbawiona jest wykształcenia” (Różycka 2009, 19), tym samym nie w pełni obiektywnie ocenia wartość edukacji. Uważa ona, że uczęszczanie dzieci romskich do polskich szkół powoduje ich polonizowanie i odsuwa od romskiej kultury i tradycji (Andrasz 2009). To ważny aspekt dotyczący edukacji uczniów romskich, ponieważ dużą rolę w procesie kształcenia dzieci odgrywają rodzice, a właściwie najbliższe środowisko domowe, co podkreśla Stefan Szuman, zdaniem którego dorośli, już od początkowego okresu, mają wpływ na dzieci, bowiem dzięki nim w słowniku najmłodszych pojawiają się konkretne wyrazy (Szuman 1968, 39-49). Poza tym bliscy pośredniczą w codziennych kontaktach dzieci, uczą ich zasad i norm obowiązujących w języku. Sposób ich porozumiewania się między sobą i z dziećmi ma wpływ na język, jakim będzie posługiwało się ich potomstwo. Niewątpliwie środowisko wychowawcze dzieci romskich oddziałuje na proces nabywania przez nie języka - podkreśla to Stanisław Grabias, zdaniem którego na proces komunikowania mają wpływ kontekst społeczny i terytorialny oraz kontekst środowiskowy (Grabias 1991). Należy zatem przyjać, że romscy rodzice, których „edukacja (...) zakończyła się niestety na kilku klasach szkoły podstawowej" (Świętek i in. 2014, 8), posługują się między sobą i dziećmi najprostszą formą komunikacji i nieświadomie uczą dzieci podobnych jakościowo form wypowiedzi (Porayski-Pomsta 1993; Dołęga 2003). Ponadto rodzice romscy, często będąc analfabetami (Program na rẹecz. spoteczności romskiej, $2003 b)^{8}$, nie pracuja $z$ dziećmi w domu, w związku z czym ich potomstwo nie może liczyć na wsparcie w zakresie czytania, pisania, odrabiania zadań domowych, co w wielu przypadkach powoduje obniżenie motywacji do nauki ${ }^{9}$ i może w związku z tym przyczynić się do zwiększenia szkolnej absencji.

${ }^{8} \mathrm{~W}$ programie mowa jest o częstym analfabetyzmie i niedostatecznej znajomości języka polskiego jako o jednej z przyczyn długotrwałego bezrobocia.

${ }^{9}$ Krótki wywiad z uczniami romskimi przeprowadzony przeze mnie w 2014 roku i dotyczący ich stosunku do szkoły składał się tylko z trzech pytań (Czy lubisz chodzić do szkoły?; Co lubisz, a czego nie lubisz w szkole, do której uczęszczasz?; Czy jest coś, co sprawia ci trudność, co chciałbyś zmienić?), ale jednoznacznie wskazuje, że uczniowie mimo trudności „Zwłaszcza z językiem polskim” (wypowiedź jednego z uczniów) lubią szkołę i nauczycieli w niej uczących. Dzieci z klas IV-VI uważały, że ich szkoła jest ciekawa, kolorowa i ładna. Pomimo że - ich zdaniem - największe trudności mają z językiem polskim, bo „nie zawsze wszystko rozumieją” (wypowiedź uczennicy), to „nie zamieniliby tej szkoły na żadną inną” (wypowiedź uczennicy). Analiza wypowiedzi uczniów pozwoliła na wysunięcie wniosków, że dzieci romskie lubią chodzić do szkoły, ponieważ mają w niej kolegów i nie czują się dyskry- 
Kwestia, która również zasługuje na uwagę, jest częsty brak przygotowania przedszkolnego romskich dzieci, który umożliwiłby im regularny kontakt z językiem polskim, a także dał możliwość integracji z grupą rówieśnicza. Przedszkole jest bowiem miejscem, dzięki któremu dzieci nawiązują kontakt z rówieśnikami, ćwiczą pamięć, motorykę małą i duża, percepcję wzrokowa, mowę (Łój, Mirga 2012). Bez tego - zdaniem jednej z asystentek romskich dzieci romskie często powtarzaja początkowe klasy, gdyż nie są w stanie w wyznaczonym czasie opanować zaplanowanego do zrealizowania materiału i sprostać wymaganiom programowym (Łój 2009). Sytuacja ta mogłaby ulec poprawie jedynie wtedy, gdyby Romowie nietraktujący edukacji przedszkolnej równorzędnie $\mathrm{z}$ tą, która rozpoczyna się w szkole, docenili umiejętności, jakich dziecko nabywa w przedszkolu (Andrasz 2009; Różycka 2009).

Dodatkowym aspektem, który znacząco wpływa na przebieg edukacji romskich uczniów, jest sposób, w jaki się porozumiewaja. Ich dwujęzy cz no ść, rozumiana jako umiejętność posługiwania się dwoma językami bez określania stopnia znajomości tych języków (Kurcz 1992), a właściwie dwujęzyczność połączona $z$ dyglosją ${ }^{10}$, bez wattpienia rzutuje na sytuację szkolną dzieci romskich. Bilingwizm w ich przypadku „wytwarza się na terenach o mieszanym składzie etnicznym, (jednak - M.P.) konieczność współżycia na co dzień zmusza przedstawicieli różnych narodowości do używania oprócz swojego języka ojczystego również języka drugiej grupy etnicznej” (Polański 1999, 130). Czyni to sytuację językową dzieci romskich nietypowa, od urodzenia mają one bowiem stały kontakt $z$ językiem romskim, a dopiero sytuacje społeczne, kontakty z rówieśnikami, sąsiadami, wi-

minowane. Rozmowy prowadzone z dziesięciorgiem dzieci odbyły się tylko w jednej z zabrzańskich szkól, w związku z czym ich wyników nie należy traktować jako wiążących.

${ }^{10}$ Ewa Lipińska zjawisko dyglosji sytuuje w obrębie bilingwizmu społecznego (Lipińska 2003). Przekonanie to potwierdza Aldona Skudrzyk, która bazując na tezach Ch.A. Fergusona i J.A. Fishmana, rozszerza je o twierdzenie, iż dyglosja nie musi dotyczyć systemów tego samego języka, może bowiem obejmować swoim zakresem dwa jakiekolwiek warianty językowe, pod warunkiem, że - jak podkreślał to już wspomniany Ferguson - jeden z nich nabywany będzie w trakcie oficjalnej edukacji (Skudrzyk 2019, w druku). Dyglosja jest więc „względnie stabilną sytuacją językowa, w której oprócz podstawowych dialektów danego języka (...), funkcjonuje różniąca się od nich pod względem strukturalnym odmiana nadrzędna o wysokim stopniu kodyfikacji (...). Odmiana nadrzędna jest najczęściej nauczana w procesie oficjalnej edukacji i ma zastosowanie w postaci pisemnej oraz w sytuacjach oficjalnych" (Ferguson 1959, 336; cyt. za: Głuszkowski 2013, 83-84). Przenosząc przywołane teorie na społeczność romska, język romani będzie tym wariantem językowym, który nabywany jest w domu, natomiast język polski stanowi strukturę nadrzędna, skodyfikowana, występującą w formie ustnej, ale przede wszystkim pisemnej, wykorzystywaną w sytuacjach oficjalnych. 
zyty w sklepach czy u lekarza powoduja, że słyszą i poznają język polski. Związane jest to silnie z procesem s ocjali za cji, o której pisałam na początku - język ro mani stanowi więc język pierwszej socjalizacji, która odbywa się w najbliższym otoczeniu dziecka. Jest on językiem „pierwszym (językiem bliskości) systemowo różnym od tego, który jednostkę wprowadza w świat instytucjonalny, oficjalny, pozarodzinny" (Skudrzyk 2019). W przypadku socjalizacji wtórnej, rozpoczynającej się w momencie życia zinstytucjonalizowanego, dziecko poznaje język drugi, język większości - język polski. Dzieci romskie porozumiewają się zatem językiem romani (L1) $\mathrm{w}$ domu, natomiast w szkole, $\mathrm{z}$ nauczycielami i uczniami pochodzenia polskiego - językiem polskim, drugim (L2). Sytuacje oficjalne narzucają więc wykorzystanie języka większości. Fakt, że przyswajanie języka polskiego odbywa się dopiero na gruncie szkolnym, powoduje problemy językowe najmłodszych uczniów, którzy rozpoczynając naukę w klasie pierwszej, bardzo słabo znają język polski11 (Kledzik 2012). Trudności te dotyczą zarówno mówienia, jak i pisania, bowiem dzieci w szkole „dopiero uczą się pisania, wchodzą w obszar kultury pisma, nie sa w tym zakresie ukształtowane" (Skudrzyk 2005, 14). Doświadczenie wyniesione z pracy nauczyciela polonisty dowodzi także, że brak umiejętności pisania dotyczy nie tylko uczniów klas I-III, ale również dzieci starszych, które często nie potrafia pisać ani czytać. Ponadto - co także wiąże się z procesem edukacji romskich uczniów - część z nich, zwłaszcza dziewczynek, które chcą żyć zgodnie z ro manipen i być wiernymi romskim tradycjom, w odpowiednim dla siebie czasie przerywa naukę i zakłada rodziny. Mówi o tym także Pełnomocnik Wojewody Małopolskiego ds. Mniejszości Narodowych i Etnicznych, zdaniem której „młodzież romska, żyjąca według tradycyjnych zasad, bardzo wcześnie zakłada rodziny, co powoduje, że już w szkole podstawowej porzuca naukę" (Mirga-Wójtowicz 2009, 77) ${ }^{12}$.

Biorąc pod uwagę niski stopień realizacji przez dzieci i młodzież romską obowiązku szkolnego, a także ogólne trudności związane z sytuacją bytową rodzin romskich, w roku 2001 wprowadzono w Polsce Pilotażowy program na rezecz. spoteczności romskiej w wojewódz̨twie matopolskim na lata 2001-2003, a póź-

${ }^{11}$ Jako nauczyciel języka polskiego i logopeda mam z uczniami stały kontakt. Dzieci poznaję na badaniu przesiewowym mowy, a później na terapii logopedycznej - wszyscy uczniowie romscy zostają bowiem do niej zakwalifikowani ze względu na trudności w posługiwaniu się językiem polskim. W czasie ośmiu lat pracy zetknęłam się jedynie z czworgiem uczniów, którzy nie potrafili w ogóle porozumiewać się w języku większości.

12 Wyniki badań przeprowadzonych w Zabrzu na trzydziestoosobowej grupie wskazuja, że w roku szkolnym 2014/2015 gimnazjum ukończył jedynie 1 uczeń spośród piętnaściorga dzieci romskich, które rozpoczęły naukę na etapie ponadpodstawowym. 
niej Rzqdowy program na ržecz spoteczności romskiej w Polsce na lata 2004-2013, których głównym celem było zaktywizowanie Romów i doprowadzenie do ich pełnego uczestnictwa w życiu społeczeństwa większościowego. Ponadto programy dotyczyły takich kwestii, jak: edukacja, zdrowie i higiena, walka $z$ bezrobociem oraz zmniejszenie liczby przestępstw na tle rasowym względem Romów (Program na ržecz spoteczności romskiej, 2003a). Rządowy program, będący kontynuacja programu pilotażowego, swoim zakresem obejmował ponadto działania związane z podtrzymywaniem i propagowaniem kultury romskiej, wiedzy o mniejszości romskiej w społeczeństwie większościowym, a także wiedzy dotyczącej zmian zachodzących w środowisku Romów w Polsce. Założenia programu rządowego, niezależnie od stopnia efektywności w zakresie zwalczania bezrobocia czy dyskryminacji, w kwestii edukacji okazały się pomocne. Stało się tak dzięki dodatkowemu wsparciu, jakie otrzymały szkoły kształcące dzieci romskie - nie tylko w postaci środków finansowych na podręczniki, wycieczki i zajęcia wyrównawcze, ale także za sprawą wprowadzenia funkcji asystenta romskiego oraz nauczyciela wspomagającego edukację romską (Program na ržecz. społeçności romskiej, 2003a).

A systent romski, będący osobą zaufaną wśród społeczności mniejszościowej, najczęściej się z niej wywodząca, to osoba, która powinna posiadać podstawową wiedzę na temat grupy, którą reprezentuje (Program na rzecz. spoteczności romskiej, 2003b). Wiedza ta dotyczy nie tylko aspektów związanych z kultura, tradycją czy pochodzeniem, ale również trudności, jakie napotykają w polskiej szkole dzieci romskie, potrzeb, jakie w związku z tym się pojawiaja, i działań, jakie należy podjać, by trudności zniwelować. Zadaniem asystenta romskiego jest pośredniczenie między szkołą a środowiskiem dziecka, jego domem (zwłaszcza w trudnych sytuacjach), pomoc uczniom romskim w odrabianiu lekcji, tłumaczenie materiału z zajęć, a także interwencja w momentach konfliktowych i trudnych. Ponadto asystenci powinni pielęgnować romską kulturę, poszerzać wiedzę dzieci na temat pochodzenia, języka, a także budować ich pozytywny wizerunek w środowisku szkolnym (Soszka-Różycka 2007; Stankiewicz 2011). Równie istotną rolę w placówkach oświatowych pełnią nauczyciele wspomagający edukację romską, którzy w odróżnieniu od asystentów - maja przygotowanie pedagogiczne, a ich kompetencje potwierdzone są instytucjonalnie. Nauczyciele ci są szczególnie ważni, ponieważ dzięki odpowiedniemu przygotowaniu znają metodykę pracy w grupach zróżnicowanych kulturowo - szczególną uwagę skupiają na tym, by na wczesnym etapie edukacji traktować uczniów romskich jak dzieci obcojęzyczne i dwukulturowe (Program na rzecz spot. romskiej, 2003b). Ponadto zada- 
niem nauczyciela wspomagającego jest wyrównywanie u uczniów romskich braków związanych z realizacja podstawy programowej, a także bieżąca kontrola postępów w nauce oraz prowadzenie zajęć wyrównawczych. Co więcej do podstawowych działań nauczyciela wspomagającego należy sprawowanie nadzoru nad frekwencją dzieci, aktywizowanie ich, pomoc w odrabianiu zadań domowych, jak również stały kontakt z rodziną (Łój 2009).

Wprowadzenie obu tych stanowisk zdecydowanie przyczyniło się do poprawy sytuacji edukacyjnej dzieci romskich, głównie ze względu na ich pośrednictwo z domem rodzinnym uczniów. Korzystając z pomocy asystentów i nauczyciela wspomagającego, sama mogłam zauważyć ogromny szacunek i zaufanie, jakimi romskie rodziny darza te osoby. Wielokrotnie w rozmowach z asystentami romskimi - prowadzonymi zarówno w szkole, w której pracuję, jak i na szkoleniach, warsztatach, dotyczących pracy z uczniem wielokulturowym - potwierdzało się moje przekonanie o tym, że zarówno nauczyciel wspomagający, jak i asystent romski, chcąc zmieniać relacje: szkoła - rodzina romska, rodzic - nauczyciel, uczeń - nauczyciel, starają się ukazywać kulturotwórczą rolę szkoły i udowadniać, że jest to miejsce, które daje szansę na uzyskanie awansu społecznego.

Nakreślone kwestie unaoczniają trudności związane z edukacją romskich uczniów. Częsty brak przygotowania przedszkolnego dzieci romskich rozpoczynających edukację w szkole, brak wykształcenia rodziców, ich trudna sytuacja ekonomiczna, a także bilingwizm połączony z dyglosją mają zdecydowany wpływ na to, w jaki sposób uczniowie pochodzenia romskiego nabywaja nowe umiejętności - zarówno te związane z językiem, jak i te dotyczące zachowań społecznych. Edukacja uczniów romskiej mniejszości etnicznej wskazuje zatem na konieczność wprowadzenia zmian „(...) bez których społeczność ta ostatecznie pogłębi swą i tak dużą marginalizację społeczną i pogłębiającą się atrofię kulturowa. One jednak wymagają czasu i konsekwentnego wspomagania procesu kreowania inteligencji romskiej” (Różycka 2009, 31).

\section{Edukacja dzieci romskich - przestrzenie nieodkryte}

Polityka państwa polskiego reguluje wiele kwestii związanych ze wspomaganiem procesu edukacyjnego m.in. uczniów romskich ${ }^{13}$, jednak ich potrze-

\footnotetext{
13 Konstytucja RP; Uchwała o mniejszościach narodowych i etnicznych oraz o języku regionalnym; Konwencja UNESCO w Sprawie Zwalczania Dyskryminacji w Dziedzinie Oświaty; Konwencja Praw Dziecka i wiele innych.
} 
by i problemy z nimi związane wciąż rosna. Odpowiednie rozpoznanie tych potrzeb wydaje się jednym $z$ ważniejszych aspektów prowadzących do podjęcia konkretnych działań. Dotyczy to nie tylko trudności związanych z nauką, ale również sytuacji społeczno-ekonomicznej romskich rodzin. „Pierwszym krokiem do skutecznej realizacji kształcenia romskich dzieci jest określenie ich uwarunkowań ekonomicznych, kulturowych i społecznych" (Świętek i in. 2014, 9). Nauczyciele, będąc tymi, którzy w dużym stopniu przyczyniają się do wychowania dzieci, muszą być świadomi, jacy są ich uczniowie, jakie mają mocne i słabe strony oraz jaka jest ich sytuacja w rodzinie. Taka wiedza pozwoli otoczyć uczniów bilingwalnych odpowiednią opieka i pomóc im odnieść sukces edukacyjny. Ponadto pedagodzy i pracownicy często nie posiadający dostatecznej wiedzy metodycznej, która przyczyniłaby się do wzrostu efektywności edukacyjnej Romów, powinni być odpowiednio przygotowani do pracy z dziećmi dwujęzycznymi i dwukulturowymi (Świętek 2016). Wiedza z zakresu edukacji międzykulturowej, pracy z dziećmi dwu- i wielojęzycznymi, dziećmi mającymi trudności w nauce jest tym rozwiązaniem, którego odkrycie mogłoby ułatwić dzieciom romskim edukację. Jest to bardzo ważne, ponieważ metodyka pracy z uczniem bi- lub multilingwalnym różni się od pracy z dzieckiem jednojęzycznym (Meyer 2016).

Przestrzenią, której odkrycie w równie istotny sposób wspomogłaby proces edukacyjny Romów, jest zakres tematyczny realizowany na poszczególnych zajęciach. Gdyby tematyka zajęć obowiązkowych została rozszerzona o lekcje związane z kulturą romską, romskimi obyczajami, a nawet językiem, prawdopodobnie Romowie czuliby się dowartościowani i nie deprecjonowaliby roli szkoły, a raczej rozwijaliby poczucie tożsamości i wspólnoty. Wiadomo, że „szkoła romska z językiem wykładowym romani, ucząca o historii i kulturze Cyganów, to pomysł na odległa przyszłość” (Szarlik 1999, cyt. za: Kwadrans 2008, 258). Warto jednak umożliwić również polskim uczniom poznanie obyczajów kolegów innego pochodzenia; ułatwiłoby im to zrozumienie deficytów i braków edukacyjnych ich rówieśników, które na co dzień dostrzegaja (Bladycz 2013). W mojej opinii wprowadzenie do szkół elementów nauki o mniejszości romskiej poprawiłoby także wizerunek szkoły w oczach Romów, a uczniom mniejszości pomogłoby zdobyć wiedzę na temat własnych korzeni i historii. By tak mogło się stać, niezbędne są pomoce dydaktyczne i podręczniki, z których uczniowie czerpaliby wiedzę, a z których korzystać mogliby także nauczyciele. Trudność stanowi jednak niewystarczająca liczba publikacji ułatwiających lepsze zrozumienie kwestii nauczania dzieci dwu- i wielojęzycznych - konieczne są więc książki z tego zakresu lub przekłady literatury obcojęzycznej. 
Przestrzenią wymagająca zmiany jest również stosunek romskich rodziców do szkoły. Zdarza się bowiem, że Romowie traktują szkołę jako organ represyjny, podobnie jak wszelkie formy edukacji formalnej. Dominuje brak wiary, że „dalsze kształcenie (poza tym obowiązującym na poziomie podstawowym) może przynieść pozytywny skutek" (Nowicka 2011, 46). Zmiana wizerunku placówki w oczach dorosłych Romów wydaje się trudna, jednak jest możliwa m.in. dzięki odpowiedniemu podejściu pracowników. To ich stosunek do kultury ucznia - na co wskazuja badania Ewy Nowickiej prowadzone we współpracy ze studentami socjologii - ma ogromny wpływ na efekty nauczania (Nowicka 2011), co oznacza, że ewentualne uprzedzenia oddziaływają na polsko-romskie relacje. Ponadto ważne jest to, by w tej (podopbie jak w każdej innej) sytuacji nastręczającej problemów zarówno kadra pedagogiczna, dyrekcja, jak i asystenci romscy dbali o kontakty z domem rodzinnym dzieci, pielęgnowali relacje rówieśnicze, rozwiązywali sytuacje konfliktowe i reagowali na ewentualne przejawy agresji. Zadaniem pracowników jest także obalanie przekonania, że szkoła, będąc miejscem zderzenia się wielu kultur, tradycji i obyczajów, staje się przestrzenią, w której „często zdarzają się sytuacje konfliktowe wśród dzieci, czego przyczyną są przekonania co do tego, że inność jest czymś niebezpiecznym i gorszym" (Doliński 2007, 64-65). Świadomość rodziców, że ich dzieci w szkole traktowane są sprawiedliwie i nie ma względem nich aktów dyskryminacji, mogłaby stać się pierwszym poważnym krokiem do zmiany postrzegania edukacji przez Romów.

Nieodkrytym, lecz równie ważnym aspektem jest stworzenie odpowiednich możliwości rozwoju i kształcenia specjalistycznego asystentów romskich i nauczycieli wspomagających. To oni mają za zadanie rozbudzać wśród dzieci romskich motywację do nauki, wskazując na istotną rolę szkoły; powinni zatem mieć odpowiednie wsparcie ze strony metodyków międzykulturowych i literatury cyganologicznej (Program na rzecz spot. romskiej, 2003a) po to, by zwiększać swą wiedzę i kompetencje w zakresie pracy z uczniem romskim. Ponadto dzięki odpowiednim szkoleniom i certyfikacji asystentów romskich ich status zawodowy zmieniłby się, co z kolei mogłoby podnieść efektywność ich pracy (Program na ræecz.społ. romskiej, 2003b).

Mimo iż edukacja dzieci romskich wciąż stanowi problem i zagadkę dla wielu nauczycieli, rodziców i uczniów, istnieje szereg możliwych działań, których podjęcie wspomogłoby proces edukacji dzieci romskiej mniejszości etnicznej. Słowacki profesor Jaroslav Balvin wymienia wśród nich m.in. pedagogiczny optymizm, zaprzestanie wysyłania dzieci romskich do szkół spe- 
cjalnych, poznawanie i rozwijanie nowych metod nauczania, współpracę romskich i nieromskich specjalistów romologii, poprawę sytuacji społeczno-ekonomicznej rodzin mniejszości, a także wspieranie osób ze środowiska romskiego, które zdobyły wyższe wykształcenie i umożliwienie im rozwijania poznanych umiejętności (Balvin 2009, 73-88). Przytoczoną propozycję można uznać za swoiste podsumowanie artykułu. Jednocześnie jednak warto zastanowić się nad tym, jak sprostać wyzwaniu, o którym mówi Balvin, aby to, co dotąd przysparzało problemów oraz było nieznane, szybko i skutecznie zostało odkryte i przyniosło korzyści nie tylko romskiej mniejszości etnicznej, ale każdej mniejszości i państwu w ogóle.

\section{Literatura}

Andrasz E., 2009, Edukacja w życiu Romów i jej wplyw na poczucie własnej tożsamości, w: Weigl B., red., Romowie 2009. Między węrówkeq a edukacja, Warszawa.

Balvin J., 2009, Romowie, sžkoła i dyskryminacja, przeł. J. Kajfosz, „Studia Romologica”, nr 1.

Bartosz A., 2008, Poznajemy historie Romów, Szczecinek.

Bernacka-Langier A., 2010, Diagnoza sytuacji uczniów cudzoziemskich w warszawskich szkołach, w: Pawlic-Rafałowska E., red., Inny w polskiej sqkole. Poradnik dla nauczycieli pracujacych z. uczniami cudzoziemskimi, Warszawa.

Bladycz R., 2013, Asystent edukacji romskiej - wersja dla zaawansowanych, w: Weigl B., Różycka M., red., Romowie 2013. Od divialań systemowych do rozwiazań lokalnych, Warszawa.

Ficowski J., 2013, Cyganie na polskich drogach, Warszawa.

Gheorghe N., Mirga A., 1998, Romowie XXI wieku. Studium polityczne, Kraków.

Gerlich G. M., 2001, Romowie. Przekeracæanie granic własnego świata, Oświęcim.

Głuszkowski M., 2013, Socjologia w badaniach dwujezyczności, Toruń.

Gostkowska M., 2011, Sytuacja ş̨olna dzieci romskich - oczami uczniów Romów, w: Weigl B., Różycka M., red., Romowie 2011. Życie na pograniczu, Warszawa.

Grabias S., 1991, Kultura stowa a sprawności komunikacyjne, „Polonistyka”, nr 7.

Grzymała-Moszczyńska H., Barzykowski K., Dzida D., Grzymała-Moszczyńska J., Kosno M., 2011, Driecko uniktane. Sytuacja drieci romskich w polskim systemie edukacji oraz ich funkcjonowanie poznawcze i jezykowe, w: Weigl B., Różycka M., red., Romowie 2011. Życie na pograniczu, Warszawa.

Gurbiel A., 2007, Cyganie w kregu Puław, w: Borek P., red., Romowie w Polsce i Europie: historia, prawo, kultura, Kraków.

Hertz A., 1960, Kasta, „Kultura”, nr 1/147-2/148.

Jakimik E., Parno-Gierliński K., 2009, Kobieta w środowisku romskim, Szczecinek.

Kledzik E., 2012, Driecko romskie w polskiej szkole - problemy komunikacji międzykulturowej, w: Filipowicz-Tokarska K., Chojnowski P., red., Bariery i/jako wyzwania w nauczaniu jezylka polskiego jako obcego, Słubice.

Kunikowski, J., 2010, Amare Roma. Nasi Romowie, Kowary. 
Kurcz I., 1992, Jezyle a psychologia, Warszawa.

Kwadrans Ł., 2008, Edukacja Romów. Studium porównawcze na praykeładzie Cz̨ech, Polski i Stowacji, Wrocław-Wałbrzych.

Lipińska E., 2003, Jezy/k ojczysty, jezyk obcy, jezyk drugi. Wstęp do badan dwujezyczności, Kraków.

Lubecka A., 2005, Tożsamość kulturowa Bergitka Roma, Kraków.

Łój M., 2009, Praca nauczyciela wspomagajacego edukacje dĩeci romskich - doswiadczenia ze szkót wroctawskich, „Studia Romologica”, nr 2.

Łój M., Mirga S., 2012, Edukacja dzieci romskich - praktyczny informator dla rodziców, Radom.

Meyer A.M., 2016, Wielojezyczna Polska - jezyk romski w kontakcie z polszczyzna, „Postscriptum Polonistyczne", nr 2.

Mirga-Wójtowicz E., 2009, Znaczenie Programu na rzecz spoteçności romskiej w Polsce w walce z. wykluczeniem społecznym Romów - perspektywa praktyczna, w: Weigl B., red., Romowie 2009. Między węrówkeq a edukacja, Warszawa.

Nowicka-Rusek, E., 2011, Szkoła, rodzina i drieci romskie, w: Kołaczek M., Talewicz-Kwiatkowska J., red., Raport końcowy z projektu badawczego: Funkcjonowanie poznawcze i jezykowe dzieci romskich uczeszcrajacych do szkót podstawowych specjalnych i masonych - konteksty społeczne, Oświęcim.

Polański K., red., 1999, Encyklopedia jezykeznawstwa ogólnego, Wrocław.

[Program na rzecz spot. romskiej, 2003a], Program na rzecz. spoteczności romskiej w Polsce na lata 20042013, Ministerstwo Spraw Wewnętrznych i Administracji, Warszawa, http://mniejszosci. narodowe.mswia.gov.pl/mne/romowie/program-na-rzecz-spole/program-na-rzecz-spole [dostęp: 24.12.2018].

[Program na rzecz spot. romskiej, 2003b], Program na rzecz, spoteczności romskiej w Polsce na lata 2004 2013, Ministerstwo Spraw Wewnętrznych i Administracji, Aneks nr 6, Romowie w Polsce - opis sytuacji, Centrum Dialogu Międzykulturowego, Warszawa, www2.mswia.gov.pl/ $\mathrm{ftp} / \mathrm{pdf} /$ aneks_nr6.rtf [dostęp: 24.12.2018].

Różycka M., 2009, W zory kultury a edukacja dzieci romskich, w: Weigl B., red., Romowie 2009. Międyy wędrówkeq a edukacja, Warszawa.

Różycka M., 2013, Raport końcony z badania ewaluacyjnego programu na rzecz. spoteczności romskiej w Polsce - fragmenty, w: Weigl B., Różycka M., red., Romowie 2013. Od dĩatań systemonych do rozwiazań lokalnych, Warszawa.

Skudrzyk A., 2005, Czy zmierzch kultury pisma? O synestezji i analfabetyzmie funkcjonalnym, Katowice.

Skudrzyk A., 2019, Dyglosja a proces socjalizacji, „Postscriptum Polonistyczne”, nr 1.

Soszka-Różycka M., Weigl B., 2007, Asystent edukacji romskiej. Konkurencja czy sz̧ansa?, w: Weigl B., red., Romowie 2007. Od edukacji mtodego pokolenia do obrazu w polskich mediach, Warszawa.

Stankiewicz I., 2011, Okiem asystenta edukacji romskiej z Elblaga, w: Weigl B., Różycka M., red., Romowie 2011. Życie na pograniczu, Warszawa.

Szuman S., 1968, Rozuój treści stownika drieci. Zagadnienie i niektóre wyniki badań, w: Szuman S., Gepertowa L., Przetacznikowa M., red., O roz̧woju jezylea i myślenia dżeckea, Warszawa.

Świętek A., 2016, Edukacja uczniów romskich w wojewódz̨twie małopolskim, Kraków.

Świętek A., Kurek S., Osuch W., Rachwał T., 2014, Jak edukowaí dįieci romskie? Propozycje dla nauczycieli w zakresie ksz̧tałcenia romskiej mniejszości etnicznej, Kraków.

Ustawa o systemie oświaty z dn. 7 września 1991, Dz. U. $1991 \mathrm{Nr} 95$ poz. 425, http://prawo. sejm.gov.pl/isap.nsf/download.xsp/WDU19910950425/U/D19910425Lj.pdf [dostęp: 01. 04.2019]. 